IRA-International Journal of Management \& Social Sciences

ISSN 2455-2267; Vol.05, Issue 03 (2016)

Pg. no. 491-496

Institute of Research Advances

http://research-advances.org/index.php/RAJMSS

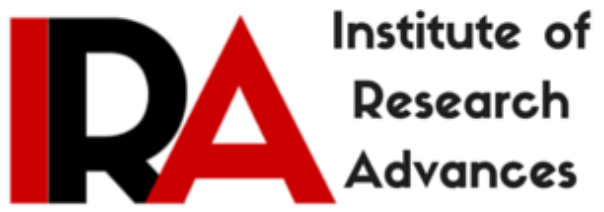

\title{
Financial Statistics and its Behavioral Implications- A Case Study of Select Hospitality Industry
}

\section{Sakshi Agrawal}

BBA III ${ }^{\text {rd }}$ Student

Narsee Monjee Institute of Management Studies (NMIMS),

Mumbai, India.

Type of Review: Peer Reviewed.

DOI: http://dx.doi.org/10.21013/jmss.v5.n3.p12

\section{How to cite this paper:}

Agrawal, S. (2016). Financial Statistics and its Behavioral Implications- A Case Study of Select Hospitality Industry. IRA-International Journal of Management \& Social Sciences (ISSN 2455-2267), 5(3), 491-496. doi:http://dx.doi.org/10.21013/jmss.v5.n3.p12

(C) Institute of Research Advances

\section{(cc) EY-NC}

This work is licensed under a Creative Commons Attribution-Non Commercial 4.0 International License subject to proper citation to the publication source of the work.

Disclaimer: The scholarly papers as reviewed and published by the Institute of Research Advances (IRA) are the views and opinions of their respective authors and are not the views or opinions of the IRA. The IRA disclaims of any harm or loss caused due to the published content to any party. 


\section{ABSTRACT}

The paper deals on Financial Statistics of Hospitality Industry vis Indian Hotels Ltd., Benaras Ltd, Sinclairs Ltd and The Grand Bhagwati Ltd. Looking at their share price and Holding period return did their portfolio and Risk Analysis. Taking their standard deviation, variance and the calculation of Sharpe Ratio did the risk analysis. The time period analyzed was from March 2010 to March 2015. The financial Statistics gives a comfortable position for the investors in terms of Returns and so a comfortable Portfolio Return Risk graph. However, a deeper analysis shows that the Profit after taxes of the respective firms are broadly not in congruence with the statistics and so the respective Returns differs. The paper takes an insight into the Behavioral implications of the Financial Statistics.

Keywords: Behavioral Finance, Holding Period Return, Hospitality Industry, Sharpe ratio

\section{Introduction}

Statistics is a quantitative discipline, which is used as a tool to represent data ranging from pure numerical analysis to real life studies. There are various methodologies and numerical techniques to draw basic quantitative analysis in the form of central tendencies, regression analysis, skewness, Kurtosis, variance and to analyze variances. This discipline is used by practically all disciplines and so Finance uses in terms of Financial Statistics. All numerical data in terms of financial annual reports share prices and other empirical data concerning the operations of the corporate world. The financial health of the companies can be judged through various tools and test given by Financial Statistical Analysis. Further, there are firm specific Financial analysis which includes amongst others bond ratings, price earnings ratios, the holding period returns, analysis of Risk and Return.

HPR: Holding period return or HPR simply refers to the total returns received from holding an asset over a period of time, It is very useful in calculating returns from an asset over different periods of time. So the formula for calculating HPR is very simple and easy. HPR $=($ End value - Initial Value $) /$ Initial Value.

Annualized average return: An annualized total return is the geometric average amount of money earned by an investment each year over a given time period. It is calculated as a geometric average to show what an investor would earn over a period of time if the annual return were compounded.

Annualized Risk: The measure of risk can be refined by dividing total risk, as measured by standard deviation, into two parts. The first part is the variation in a stock's return that results from general market movements and is referred to as systematic risk. The second component is the variation that results from factors unique to the individual firm and is referred to as unsystematic risk. Systematic risk is measured by the statistic beta (j). Beta represents the volatility of an individual security relative to the average market volatility.

\section{Hospitality Industry}

As per the Department of Industrial Policy and Promotion the Indian tourism and hospitality industry has emerged as one of the key drivers of growth among the services sector in India. Tourism in India has significant potential considering the rich cultural and historical heritage, variety in ecology, terrains and places of natural beauty spread across the country. The industry is expected to generate 13.45 million jobs across sub-segments such as Restaurants (10.49 million jobs), Hotels (2.3 million jobs) and Travel Agents/Tour Operators (0.66 million). The Ministry of Tourism plans to help the industry meet the increasing demand of skilled and trained manpower by providing hospitality education to students as well as certifying and upgrading skills of existing service providers.

India has moved up 13 positions to 52nd rank from 65th in Tourism \& Travel competitive index. 
Market Size Total outbound trips increased by 8.7 per cent to 19.9 million in 2015. Inbound tourist volume grew at a Compound Annual Growth Rate (CAGR) of 6.8 per cent during 2010-15. Foreign Tourist Arrivals (FTAs) in India increased 11.8 per cent year-on-year to 670,000 tourists in August 2016, while Foreign Exchange Earnings (FEEs) from tourism increased 13.1 per cent year-on-year to Rs 12,903 crore (US\$ 1.92 billion), as per the data from the Ministry of Tourism. Tourist arrivals in India on eTourist Visa (e-TV) grew by 196.6 per cent year-on-year to 66,097 tourists in August 2016, attributable to the introduction of e-TV for 150 countries as against the earlier coverage of 113 countries, according to data from the Ministry of Tourism.

Online hotel bookings in India are expected to double by 2016 due to the increasing penetration of the Internet and smart phones.

The tourism and hospitality sector is among the top 10 sectors in India to attract the highest Foreign Direct Investment (FDI). During the period April 2000-March 2016, the hotel and tourism sector attracted around US\$ 9.23 billion of FDI, according to the data released by Department of Industrial Policy and Promotion (DIPP).

Review of Literature: In the recent times the behavioral aspects of financial data is very much the concern of all researchers and the financial world is growing by understanding the sensitivity of other factors qualitative or vaguely defined quantitative data. The basic concern for research is to how to incorporate the different variables in the existing model or taking out more advanced levels of financial models to understand the basic nature of change in this dynamic world.

In the paper 'Behavioral finance in financial market theory, utility theory, portfolio theory and the necessary statistics: A review' by Prof. David Narwrocki and Prof. Fred Viole, explain the importance of Utility Theory to understand behavioral finance and Portfolio theory. They state "Given the heterogeneous population at the market and individual security level, we suggest that nonparametric nonlinear statistics are best suited for descriptive and inferential analysis of all possible investor preferences."

Another study done by Prof. Nikos S. Thomaidis in his paper "The Implications of Behavioral Finance for the Modeling of Securities Prices" states that the' findings of behavioural finance often suggest a new approach to the modeling of securities prices and other financial phenomena.' His paper works on as to how the investors are lead not by rationality but also by their cognitive biasness. The economic they however believes in rationality which assumption of late needs to be challenged or needs more refinement.

The paper 'Behavioral Finance and Its Implications for Stock-Price Volatility', by Prof. Robert A. Olson states that 'the newer theories of chaos and adaptive decision making, which have a place in behavioral finance, can help explain the puzzle of stock-price volatility.' The paper works and explains the importance of behavioural finance and its implications.

Similarly the report given by Melissa A.Z. Knoll, ' The Role of Behavioral Economics and Behavioral Decision Making in Americans' Retirement Saving s Decisions' in the Social Security Bulletin, states "Traditional economic theory posits that people make decisions by maximizing a utility function in which all of the relevant constraints and preferences are included and weighed appropriately. Behavioral economists and decision-making researchers, however, are interested in how people make decisions in the face of incomplete information, limited cognitive resources, and decision biases."

Another report on 'Effects of Behavioural Finance on Emerging Capital Markets' by OECD states that "it is becoming increasingly difficult to understand how the economy as a whole works. Although the 
efficient market theory might be considered an ideal model enabling the interpretation of market behavior, it has begun to lose ground, and the rationality hypothesis failed to explain the excessive volatility of the returns and trading volume recorded on both developed capital markets and emerging ones. Adding the behavioral finance perspective to the equation can help us to understand better how market agents will react."

Research Methodology: The paper is quantitative and descriptive in nature. The holding period return and their standard deviation, Variance, risk analysis and Sharpe ratio is calculated from the time period ranging from March 2010 to March 2015, of the hospitality Industry vis Indian Hotels Ltd., Benaras Ltd., Sinclairs Ltd. and The Grand Bhagwati Group. The numerical values are then compared with the financial statements of these respective firms.

Analysis is done on secondary data.

The study is limited to the time frame and is in the form of a case study limited to hospitality Industry. The time period analyzed was from March 2010 to March 2015.

\section{Data Presentation \& Interpretation}

The share prices of the four players were analyzed and their holding period Return, standard deviation, annualized annual return and annualized risk along with their Sharpe ratio were calculated, which are represented in the given two tables:

Table 1

\begin{tabular}{|l|l|l|l|l|l|}
\hline STOCK & HPR & $\begin{array}{l}\text { Standard } \\
\text { Deviation }\end{array}$ & $\begin{array}{l}\text { Annualized } \\
\text { Annual Return }\end{array}$ & $\begin{array}{l}\text { Annualized } \\
\text { Risk }\end{array}$ & $\begin{array}{l}\text { Annual } \\
\text { profit/Loss }\end{array}$ \\
\hline $\begin{array}{l}\text { Indian Hotels } \\
\text { Ltd }\end{array}$ & 0.005940864 & 0.090003676 & 0.07129 & 0.3112 & $(270.46)$ \\
\hline Benaras & 0.026004352 & 0.106659998 & 0.31205 & 0.3694 & 828.56 \\
\hline Sinclairs & 0.017519231 & 0.145146721 & 0.21023 & 0.5280 & 705.5 \\
\hline TGB & 0.02313914 & 0.176945311 & 0.272 & 0.613 & $(1544.07)$ \\
\hline
\end{tabular}

As per the above table the annualized returns approximately are $7 \%, 31 \%, 21 \%$ and $27 \%$. This is calculated on the basis of the stock price prevailing in the market during the referred time.

The reflection of the annual reports of the respective firms show that two players viz the Indian Hotels and The Grand Bhagwati have shown losses in their annual financial statements.

As per the portfolio theory the Sharpe ratio calculated is as given in table 1.2

Table 1.2

\begin{tabular}{|l|l|l|l|}
\hline Portfolio Return $(\mathrm{Rp})$ & Risk free rate of return $(\mathrm{Rf})$ & Std. Deviation & Sharpe Ratio \\
\hline 0.20 & 0.08 & 0,21 & 0.62 \\
\hline
\end{tabular}

The Sharpe ratio is the ratio between the excess of portfolio return over the risk free rate of return divided by the Standard deviation, which in this case is 0.62 . The ratio depicts the volatility in the change of the portfolio return. 
Table 1 depicts that that TGB has the highest volatility due to high standard deviation and Indian Hotels Ltd. on the other hand having the least deviation. The annualized risk factor of Benaras Ltd. and Sinclairs Ltd. is about $37 \%$ and $53 \%$. The PAT of these two companies are showing profit not only in this year but also has a tradition of earning profits, though their risk level is comparatively high.

On the other hand a similar level of annualized Risk factor for the TGB ltd. and Indian Hotels Ltd. which is approximately $61 \%$ and $31 \%$

As per the holding period return data the Portfolio return earned is $20 \%$ and since the time the data was taken the Indian economy data showed a boom in the hospitality industry and hence risk free rate of return is taken as $8 \%$.

\section{Interpretation}

The above case study analysis depicts the following things:

1. All Portfolio analysis should be taken along with the financial analysis of the firm, as at times the share prices do not reflect the intrinsic value of the share and may be overpriced or underpriced due to some other random factors which are not accounted for.

2. The portfolio return calculated of a particular investment combination can reflect a different rate of return and the actual rate of return in terms of Profit after tax and undistributed profit may be opposite to each other.

3. The risk free rate of return, among the other two factors viz portfolio return and standard deviation of the portfolio will determine the Sharpe ratio. The Sharpe ratio may range from positive and negative infinity depending upon the feature of these three variables. Ideally Sharpe ratio may range from one to two, as per the different empirical research done on the topic, which would mean the desirable returns. The Sharpe ratio in this case calculated is 0.62 with a comparatively high risk free rate of return if the $\mathrm{T}$ bills rate of return is taken as a proxy the Sharpe ratio will be higher, signifying that the returns on the portfolio is desirable. The Annual report of the Indian Hotels and the Grand Bhagwati show losses and the Holding Period Return are 0.0059 and 0.0231 , the data shows that still there are returns from theses investment and the appropriations naturally will show that the dividends distributed are nil due to losses made. The point to be considered here is that the quantitative analysis of Portfolio theory should be in consultation with the financial environment of the players in the portfolio analysis. No matter which tool is being used for analysis, what is important is their behavioural aspects which can be studied in congruence with their financial aspects. The share prices or the equity market must include in their analysis the true quantitative variables of the financial health of the company.

4. This would mean that a cognitive analysis of the quantitative Portfolio result has to be considered as underscored by Prof. Nikos S. Thomaidis.

5. Along with the different parameters the non parametric measures should be included for model formulation.

The portfolio theory and the financial theory must identify different variables parametric or non parametric theory to be a perfect judge of the different investment analysis. A case study supported for this purpose.

\section{References}

1. Asquith, P., Bruner, R. and David Mullins, J., 'The gains to bidding firms from merger', Journal of Financial Economics, Vol. 11, 1983, pp. 121-39.

2. Avramov, D., Chordia, T. and Goyal, A., 'Liquidity and autocorrelations in individual stock returns', Journal of Finance, forthcoming. 2006. 
3. Baker, M. and Stein, J. C., 'Market liquidity as a sentiment indicator', Journal of Financial Markets, Vol. 7, 2004, pp. 271-99.

4. Bakshi, G. S., Cao, C. and Chen, Z., 'Do call prices and the underlying stock always move in the same direction', Review of Financial Studies, Vol. 13, 2000, pp. 549-84.

5. Brennan, M., Chordia, T. and Subrahmanyam, A., 'Alternative factor specifications, security characteristicsand the cross-section of expected stock returns', Journal of Financial Economics, Vol. 49, 1998, pp. 345-73.

6. Chan, W. S., Frankel, R. and Kothari, S. P., 'Testing behavioural finance theories using trends and sequences in financial performance', Sloan Working Paper. (MIT, 2003).

7. 8.Fama, E. F. and French, K. R., 'Common risk factors in the returns on stocks and bonds', Journal ofFinancial Economics, Vol. 33, 1993, pp. 3-56.

8. Fama, E. F. and MacBeth, J., 'Risk, return and equilibrium: Empirical tests', Journal of Political Economy, Vol. 81, 1973, pp. 607-36.

9. Huh, S.-W. and Subrahmanyam, A., 'Order flow patterns around seasoned equity offerings and their implications for stock price movements', International Review of Finance, Vol. 5, 2005, pp. 75-111.

10. Hvidkjaer, S., Small trades and the cross-section of stock returns', Working Paper (University of Maryland, 2005.)

11. Hvidkjaer, S., 'A trade-based analysis of momentum', Review of Financial Studies, Vol. 19, 2006, pp. 457-491.

12. Jegadeesh, N. and Titman, S. 'Returns to buying winners and selling losers: implications for stock market efficiency', Journal of Finance, Vol. 48, 1993, pp. 65-91.

13. Jegadeesh, N. and Titman, S., 'Cross-sectional and time-series determinants of momentum returns', Review of Financial Studies, Vol. 15, 2002, pp. 143-57.

14. Jensen, M. and Ruback, R., 'The market for corporate control: the scientific evidence', Journal of Financial Economics, Vol. 11, 1983, pp. 5-50.

15. Kamstra, M. J., Kramer, L. A. and Levi, M. D., 'Losing sleep at the market: The daylight-savings anomaly', American Economic Review, Vol. 90, 2000, pp. 1005-11. 